\title{
Aesthetical Transformation on Ramayana Stories of Indonesia- Thailand Versions
}

\author{
Robby Hidajat ${ }^{1, *}$ Pujiyanto ${ }^{2}$, Hartono $^{3}$, Muh. 'Afaf Hasyimy ${ }^{4}$ \\ ${ }^{1-4}$ Department of Art and Design, Faculty of Letters, State University of Malang, Indonesia \\ *Corresponding author. Email: robby.hidajat.fs@um.ac.id
}

\begin{abstract}
Aesthetical transformation of Ramayana stories in Indonesia and Thailand has a power that can substantiate the existence of each entity in developing their own culture. Aesthetical aspect are presented in various expression media, including visual art (fine art) and performing art. Ramayana performing arts in Indonesia and Thailand is leaning on Hindu spirituality and has been adapted as a part of local expression. Both Indonesia and Thailand versions of performing arts involves ethnical expression to capture visual, kinetical and auditorial senses of the audiences. Performing arts always remain flexible to be adjusted to people life. The objective of this research is to describe and review the aesthetical transformation of Ramayana stories expressed through performing arts. Research method is qualitative descriptive involving structural functional theory approach. Data are collected through depth interview, observation, and documentation review. Data analysis technique is hermeneutic interpretation to identify the elements of aesthetical transformation in literary function of Ramayana stories. Result of this research shows that literary aspect of Indian epical stories has been presented aesthetically in the form that can be adjusted to people culture. Performing arts has undergone transformation to become "the show" to educate morality value.
\end{abstract}

\section{Keywords: Aesthetical Transformation, Ramayana Stories, Literary Parallelism, Performing Arts}

\section{INTRODUCTION}

Aesthetical transformation on Ramayana stories of Indonesia-Thailand versions has not been intensively discussed, at least specifically on its relation with performing arts. Previous reviews only explored the history of performing arts and considered presentation model as a form of art creation [1], either as a genuine art or a craft [2]. Unfortunately, focus on aesthetical transformation on Ramayana stories of IndonesiaThailand versions is delimitated to the exploration of formalistic aesthetical value that involves viewpoints of literacy (literary art) and visualization (fine art). Social issues in Thailand have made Thailand cultural conservers give more focuses on cultural aspect of aesthetical transformation, which refers to the acculturation of aesthetical value to Buddhism spiritual practice [3].

The archaeological transformation aspect of Ramayana carvings on Candi Prambanan have been investigated by archaeological reviewers [4]. Art creations that took reference from Ramayana carvings on Candi Prambanan were still successful in drawing attentions of audiences, and those creations were still produced by academic artists in Bali [5]. Intensive exploration on candi's carvings, including Ramayana carvings was also done on various candi in Java, Indonesia [6].

Not only this research examines aesthetics comparatively, but it also reviews the absorption (adaptation) of performing arts by Indonesia or Thailand to one another through their ethnicity potentials. Indonesia and Thailand have developed what so called parallel ethnocultural relationship although each has ethnic cluster that emanates from different historical background, which has different sociocultural establishment that surely grows dynamically in different way.

Despite those differences, Indonesia and Thailand similarly have strong local ethnicity uniqueness. Likewise, both have the so called social immunity that enables them to absorp outside influence to be the integral part of their realm.

It must be noted that Indonesia and Thailand have built inter-ethnic relationship since VII century. King of Thailand received a set of gamelan from Java delegations 
(Java now as a part of Indonesia), and then stored this traditional music instrument at Thailand National Museum in Bangkok. It is then less surprising if both countries still retain this diplomatic relationship to a relatively new form of cooperation, which is, promoting tourism through performing arts. The current research also discerns the pioneer action initiated by Department of Tourism when it invited professional performers to play Ramayana stories on Prambanan Theatrical Complex for the first time in 1961 [7]. Same invitation to Prambanan was also given in 1995 and 2015 (Sumardi, Interview, 2019). This strong connection exists because Indonesia and Thailand have ethnocultural relationship, at least regarding with Ramayana performing arts because Ramayana stories are very popular among people in Southeast Asia.

Ramayana stories in Indonesia are disseminated differently from that in Thailand. This difference is still persistent although both countries have similar functional necessity upon Ramayana stories, which is, to internalize moral and spiritual characteristics into national identity. In case of Indonesia, Ramayana stories give an emphasis on the importance of Brahmana as spiritual advisor to the King. In the ancient context of Indonesia and Thailand, the existence of kingdom is supported by three pillars, namely (a) spiritual advisor, (b) royal power (represented by the King), and (c) legal system [8]. However, aesthetical aspect of Ramayana stories is not yet revealed, especially in relation with the transformation of Ramayana stories from its original source in India to the realm of two countries examined in this research, precisely Indonesia and Thailand.

Previous research used as reference is a book titled with Migration of Ramayana Stories through IndonesiaThailand's Tourism Performing Arts [9]. This book asserted that there is a difference in transformation and adaptation potentials of Ramayana stories in Indonesia and Thailand. Both are ethnical states, and therefore, this difference is influenced by historical, sociocultural, spiritual aspects of the people, and also people struggle to achieve modernity. Cultural transformation, therefore, cannot be separated from the achievement of modernity. Functionally, there is always a cultural contribution to the development of Ramayana stories in modern days, which precisely is, the presence of aesthetics to substantiate morality ethics in various life aspects of the people.

This research attempts to review the aesthetical aspect of Ramayana performing arts in Indonesia and Thailand, and it is done by investigating the role of aesthetical transformation in enshaping visual, kinetical and auditorial elements of performing arts. The point of transformation in this context is referred to the early function of Ramayana stories as "guidance" [10]. Such guidance is associated with education, which makes the transformation of Ramayana stories influence the development of morality ethics in people posture [11].
Institutions involved in this transformation is educational institutions, which are not only used to deliver morality ethics to people but also assigned to educate the people about the expected character [12]. People are educated with aesthetics in order to convince them to have personal identity that is related with historical factor. In this modernization era, education becomes "the show". Various collaborative works have been built by art workers in presenting Ramayana stories on Prambanan stage, and these works are the indication of how to educate the people in modern day [13].

Aesthetical transformation of Ramayana stories in Indonesia and Thailand is expressed through performing arts. Aesthetical aspect affects the characteristic and pattern of social life. Symbolically, it changes not only the way of audiences in understanding the characters in Ramayana performing arts but also the development of literary function in that performing art.

\section{METHOD}

Three key informants are involved in this research and they are the experts and practitioners of relevant performing arts. These informants are Suyanto (60 years old), the lecturing staff at Indonesia Art Institute of Surakarta and also professional puppeteer of East Java style puppets; M. Soleh Adi Pramana (67 years old), professional puppeteer at Padepokan Seni Mangundharma Tumpang Malang; and Surasak Jamnongsarn (57 years old), an ethnomusicologist at Department of Traditional Thai and Asian Music, Faculty of Fine Arts, Srinakharinwirot University. All these informants were sorted over from 50 randomly selected respondents who are considered representing educational institutions, performing art societies, and performing art practitioners in Indonesia and Thailand. Researchers conducted intensive discussion and explored the implication of aesthetical transformation of Ramayana stories in Indonesia and Thailand. The selection of research location in Indonesia and Thailand took into consideration of several conditions that influence the development of Ramayana performing arts. Verbal data were supported with observation on Ramayana show played on Prambanan Open Stage in Central Java, on Kecak Ramayana at Uluwatu Temple in Denpasar, Bali, and Ramakien (Thailand version of Ramayana) on Theater of Thai Masked Dance Sala Chalermkrung in Bangkok, Thailand. Documentation review is done by making records from videos or photographs to develop understandings through visual aspect. Method of research is qualitative descriptive that involves two approaches, namely structural functional theory [14] and hermeneutic interpretation [15], which are considered helpful to researchers in understanding the elements that constitute Ramayana performing arts in Indonesia and Thailand. 


\section{DATA EXPOSITION}

Ramayana stories are widely disseminated throughout Java and Bali due to the rise of kingdoms. In the heyday of Hindu culture in Indonesia [16], Ramayana stories were used as the material of spiritual teaching inside palace environment. During the golden era of Hindu culture in Java, Ramayana stories were conveyed by Brahmana [17] to become moral system for nobilities. Therefore, Brahmana's position is functional, precisely as spiritual advisor to the king [18]. As a form of rites that involves an offering of servitude to the king, it is not surprising if Ramayana stories are presented visually, precisely in the form of either murals or candi's carvings [19].

Carvings on Candi Prambanan in Central Java and those on Candi Penataran in East Java are structural in nature, which describes the position of area, kingdom or places where the stories occur. Based on the result of observation, Candi Siwa and Candi Brahma are positioned at two different spots. Candi Siwa refers to the place of Rama and Sinta in Ayodya, whereas Candi Brahma is the imagination of a place across the sea, precisely Alengka where Rahwana resides. Moreover, Ramayana stories are played in the environment of Uluwatu Temple, which is famed with long-tail monkeys wandering through some parts of the Temple. This view gives impression of the position where Ayodya Kingdom resides and also regarding the time when the armies of monkeys are organized to cross to Alengka. Ramayana stories are also presented at Theater of Thai Masked Dance of Sala Chalermkrung in Bangkok, Thailand. The stage where the show is held is located at the southern of Grand Palace. It is not accidentally arranged in that way but it is indeed intentionally designed to produce aesthetical impression. Probably, this is associated not only with geocultural principle used by the conceiver of Ramayana stories but also aesthetical transformation of these stories as the object of spiritual comprehension.

Ramayana stories played through performing arts were very popular entertainment during the reign of Javanese kingdoms in the age of colonialism, and the play of these stories took various forms including leather puppet and man puppet, which were used to present either certain part of story (petilan) or whole story [20]. Various shows of Ramayana stories had been held by the kings in four Javanese kingdoms (Kasunanan Surakarta, Kadipaten Mangkunegaran, Kasultanan Yogyakarta, and Pura Pakualaman) in the end of XVII century [21]. These phenomena gave a proof that the show of Ramayana stories in Central Java was growingly dynamic, especially when it is played as ritual presentation. However, according to Suyanto, one of informants, East Java people were not quite fond of Ramayana stories, and thereore, the stories were not so popular in eastern part of Java Island. In the other hand, another informant, M. Soleh Adi Pramono successfully identified that Panji stories played by Malang mask puppet (Malang is a part of East Java) were indeed inspired by Ramayana stories. It seems that both stories promote same values, more or less, such as strong romance bonding, exemplary behavior, loyalty in love, and the flux of household life.

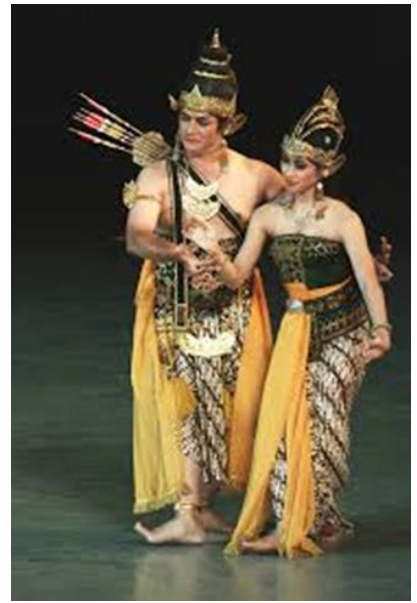

Figure 1 Rama and Sinta as a couple in romance narrative (https://borobudurpark.com)

In Bali, Ramayana stories were usually played in the form of leather puppets. Earlier, the play was dominated by nobilities but now, the common people can entertain audiences with Ramayana stories by playing it as Kecak Dance. It is an indication of transformation and it begins with the sense of solidarity. Kecak Dance is a communal dance that involves symbolical interaction of individuals [22]. Such interaction is a condition that generally occurs in Indonesia.

Ramayana stories help internalizing moral values to the nobilities at governmental offices. It is hoped that the values will convince the nobilities to see the king as a transformative pattern bequeathed to them by the deities as cosmos constellation responsibility [23].

In general, the materialization of Ramayana stories in Java Island has taken various forms such as scripts, performing arts, and carvings on candi's wall. One reason of this materialization is that the rulers felt necessary to educate the people about the kingdom through observable materials. The other reason is that public education institutions did not exist yet at the time. In the beginning, only scripts and candi's carvings provide "guidance" for the rulers to enshape the social, cultural, mental, and spiritual characteristics of the people.

As time goes, scripts and candi's carvings are then presented as "the show", which suppose to be played in front of many audiences. Despite its original function to educate people, the show must be designed to produce recreative situation, managed flexibly, and aimed to entertain the audiences. Therefore, philosophical essence is suppressed, whereas visualization is asserted. In this context, the visual aspect of the show is determined by some elements such as costume, formation and figuration of dancers, light management, and attractive setting. Besides the elements of visual aspect, the destination 
(location) itself can raise visual sensation, like the show of Kecak Ramayana in Pura Uluwatu. The show is usually played ahead of sunset and it is believed that it will give dramatic sensation. Rahwana character is always defeated when the sun goes down. Symbolically, it indicates that Dewa Siwa is no longer giving bless to Rahwana.

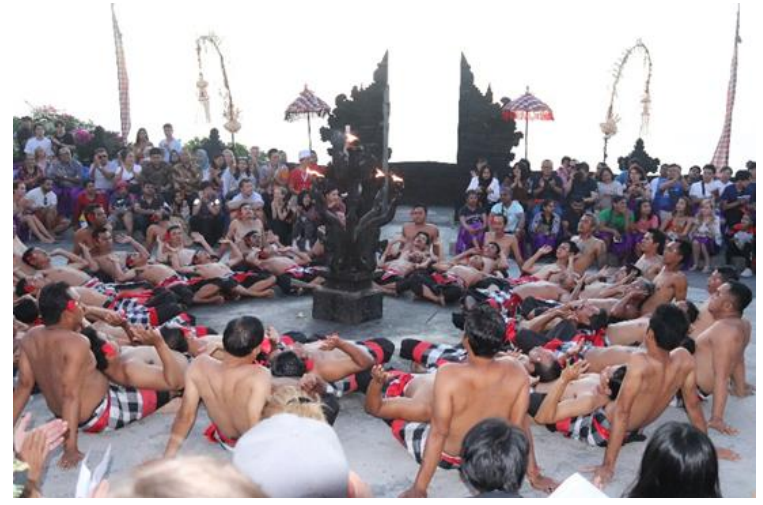

Figure 2 The Show of Kecak Ramayana in Pura Uluwatu, Denpasar, Bali (photograph collection by Hidajat, 2019)

Since 1995, Sunardi has been periodically invited to play Ramayana stories on Prambanan open stage. He is the leader of performer group that specializes on playing Ramayana stories in Yogyakarta style. The play is usually held from May to October every year. His creative work with "Ramayana Ballet" Group is truly his effort to explore the vision of Ramayana stories. He reaped the fruit of his work when he and his group were given opportunity to conduct collaboration work with Ramakien Group assigned by Department of Tourism for Thailand.

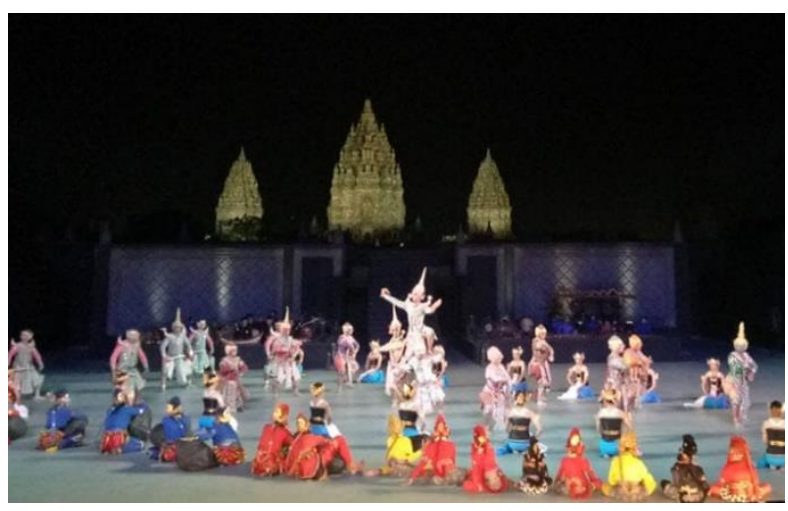

Figure 3 Collaboration Work of Ramayana Performer Group from Indonesia and Thailand (https://radarjogja.jawapos.com)

First collaboration work was done in 1995. During their collaboration, both Indonesia and Thailand groups decided which scenes they should play. It was then decided that they play only scenes that describe the strong bonding between Rama and Sinta. For instance, the journey of Rama and companions to Dandaka Forest was played by Thailand dancers only. The abduction of Sinta by Rahwana was presented by Indonesia performers only but Hanoman's mission to Alengka was played by Thailand dancers. Finally, the battle between good and evil was presented together with Rama and Hanoman played by Indonesia crews, while Rahwana acted out by Thailand dancer. In 2015, Indonesia and Thailand groups met again to conduct second collaboration work. Each group not only played scenes of Ramayana stories but also looked for the essence of the stories. In the end, both groups were satisfied to each other's performance, while admitting that they have same vision on presentation of Ramayana stories.

\section{ANALYSIS AND RESULT}

Novelty aspect in result of this research is about literary parallelism of Indian stories in other countries, which in this context is Indonesia and Thailand. The stories firstly developed in India on IV century and then spread throughout various regions in Southeast Asia. However, the transformation of the stories in every region did not produce parallelism because in each region, the stories had evolved into having different structure, plot and content. Such evolution is called functional elaboration, where the stories are changed in conformity to social necessity. The way of these stories disseminate in Indonesia is greatly different from that of Thailand. This position is in alignment with functionalism perspective, which says that the life of people in a certain area is always organic [14]. The life aspects that support the survival of people in this area are in relation to one another. Social elements that grow and develop in certain ethnic area will always follow their social necessity [24].

Textually, the variation of every literary work, either verbal or non verbal, is associated with functional structure of its conserver society. The presence of Ramayana stories as scribal transcription is different from its presentation as performing arts. Over times, the conserver society of Ramayana stories in Indonesia and Thailand must face different necessity and receive different treatment. The current research focuses on this topic.

Ramayana stories did not just disseminate to Indonesia or Thailand without reason. Indeed, the stories were brought from India for fulfilling one certain function, which is, to support social and political interests of the rulers. In the age before Hindu culture development, Indonesia people live nomadically in colony. After they profess Hindu culture, they begin to live permanently and become more established and more organized. They even have good people to be the exemplary, and differentiate work system based on social stratification [24]. This transformation creates a new necessity to establish a new form of ruling called dynasty. Later, many chiefs of tribes experience what so called political transformation and become the rulers with certain territory. Consequently, the ruling is no longer held by someone in absolute manner, and the structure containing elements that support the ruling is then 
needed. One of these elements is spiritual board. Convinced by the benefits of this system, some local rulers invite priest (Brahmana) from India to come to their palace, or send few learned persons to study religion in India.

According to cultural dissemination theory, the arrival of Brahmana, therefore, is not only to change the ideology of people. The priests or religion elders are assigned to the palace to function as assurance that the king will have stronger position on the eye of people. Priests act as spiritual advisor to the king, and they will convince people to obey their king, at least by saying that king's religion is people's religion. It can give the king a political legitimacy, where kingdom's religion will be people's religion. Priscilla Yema Marselia said that political orientation is always used to strengthen spiritual aspect of the kingdom, which later it influences the way of the king and people in professing the religion [25].

\subsection{Integration of King and People}

Ramayana stories do not legitimize the spirit of proletarian, and therefore, the stories do not have anything to do with class equality promoted by Marxism. Ramayana stories talk about the unification of human and nature (including animals) to fight back the destroyer of human morality. This fight is done through natural transformation initiated by the incarnation of Dewa Wisnu. It must be noted that every age experiences the so called cosmical chaos, and therefore, the effort to uphold the dynasty or kingdom will always involve keeping in companion of spiritualists in addition to having reliable warlord and preparing a lot of soldiers.

Ethnic kingdoms that emerge in Southeast Asia have positioned Brahmana as spiritual advisor. To ensure that the kingdom will be more established, Brahmana not only educates people on how devote themself to the king, but also represents the existence of the king. In this matter, king must be put as the most important person in social moral model. Therefore, a concept called 'dewa raja' [26] was used to internalize spiritual ideology to the people, and Javanese people called this concept with a term "manunggaling kawula gusti" [27]. However, Ramayana stories are not truly describing the integration of king and people, but only indicating symbolically the unification of human and nature.

Not only the kingdom is supported by three pillars but also the puppet play (wayang). The existence of spiritual power in puppet play is represented by a form of triangle. Puppeteer as one pillar symbolizes the king and acts as pancer (center). The other pillars are bala kiwa, located at the right of puppeteer, mostly consisting of antagonist characters and bala tengen, put at the left of puppeteer, mostly comprising of antagonist characters. Both characters are arranged in a row, and this arrangement is called simpingan. The puppet play is enlightened with blencong (oil lamp), which is placed above the puppeteer and symbolizing transcendental substance. The following scheme shows the detail.

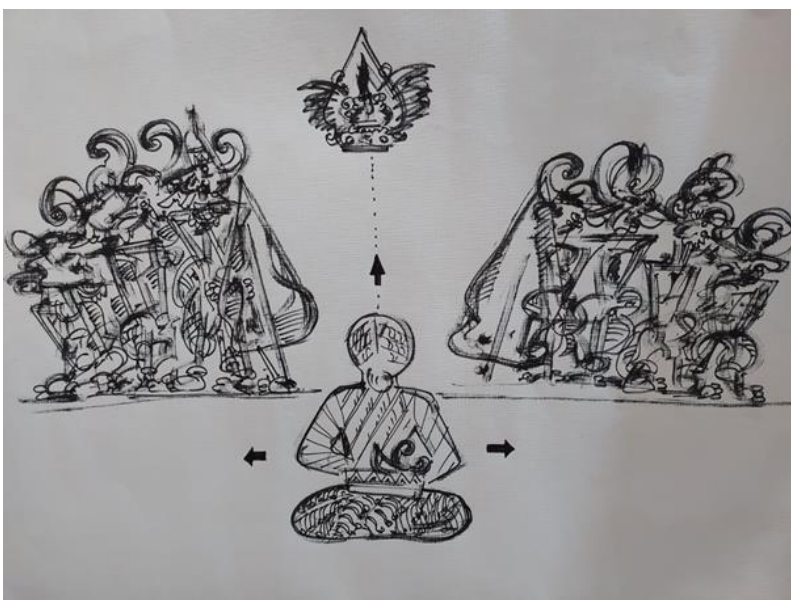

Figure 4 Triangle of Manunggaling Kawula Gusti (Hidajat, 2020)

Triangle concept is also used within the context of this research, precisely concerning with Ramayana stories, but it is applied in rather transformative way. In simple application, the triangle comprises of three main characters in Ramayana stories, which are arranged as follows: bala kiwa (Rahwana) - puppeteer (Rama) - bala tengen (Hanoman). The oil lamp signifies Dewa Wisnu. This triangle is also the manifestation of functional structure that organizes the life of kingdom and the people. Rulers must know who is their friend and who is their enemy, and both will be kept in a dynamic balance. Dramaturgy system is used by researchers in analyzing this triangle concept, or at least, it is used as an aesthetical principle when researchers read Ramayana stories to understand the position of main characters.

\subsection{Establishment of Social Morality}

Besides helping to integrate king and people, other function of Ramayana stories is to establish social morality, which is done by teaching the importance of obedience to morality law. Suyanto, one of research informants, associates it with the principle 'sura dira jaraningrat, lebur dining pangastuti', which denotes that who is wrong will be destroyed. If human is proven as doing wrong, either intentionally or accidentally, they will be forced to subject to morality law.

When Rahwana abducted Sinta, the morality law condemned this action as absolutely wrong. Javanese people call this crime as 'merusak pager ayu' (destroying other's household). Despite this heavy accusation, Rahwana excused that the abduction is the way that he chose to show his power and dignity as a king. The reason to take a war with Rama is not merely about invading other's territory with military invasion and even through colonization. Perhaps, Thailand people agree with this principle, at least because Thailand is the only state in Southeast Asia that is not colonized by west countries. It 
seems that European countries find difficulty to colonize Thailand, probably due to its strong spiritual power. The colonization of Indonesia, especially Java, is preceded by the political tactic of deceiving Javanese kingdoms to fight against each other, and then, they become weak in facing the colonizer. Internal conflict among Javanese kingdoms has its resemblance in Ramayana stories, precisely in the sibling conflict of 'Sugriwa-Subali', which is caused by many reasons, including 'woman' as the strongest trigger, followed by wealth, position, and power territory. The journey of royal power always involves political recognition, and this recognition is often gotten from woman. In the perspective of legal system, royal woman is given a position as high as man because they are blessed with the right to choose and determine any man who deserve to be their husband. Apart from this right, woman still needs protection, especially from the risk of being abducted or stolen. Such abduction has become a popular theme in the play of Panji stories, which is a popular play in East Java. The stories are talking about the effort of Raden Inukertapati to find Dewi Sekartaji who has bee abducted by Prabu Klana Sewandana from Kerajaan Sabrang or Bantarangin [28].

Researchers may not yet explore deeply the functional structure of woman position in effort to support political standings. In relation with Ramayana stories, one thing that must be known is that Rahwana did not humiliate or even violate Sinta for 12 years after abduction. This self-control is the proof of Rahwana's obedience to the essence of Hindu religion law that prohibits any man from violating wife of other man. Also, Rahwana's self-restraint confirms his spiritual fidelity as the adorer of Dewa Siwa.

Being the main antagonist character in Ramayana stories does not reduce Rahwana's strong observance to the existing social norms. Even, Rahwana successfully implemented spiritual morality principle at least in partial manner because he can restrain himself from abusing power although he has opportunity for it. However, the fidelity to spiritual morality principle is considered more noble than the respect to sociopolitical norms. When the nobilities are able to show good morality, they become good exemplary regardless their sociopolitical skills. Wibisana, a younger brother of Rahwana, is possibly a person of this situation, especially when he decides to betray Rahwana and join Rama. The audiences of Ramayana stories always have a notion that Wibisana has made a good decision, and even he is regarded as "hero of truth". Despite his betrayal to his brother, Wibisana personality has been transformed by Hindu spiritual norms into a correct position. However, in some states, including Thailand, what Wibisana did is seen differently by the existing social moral norms. The presentation of Ramakien (Ramayana stories of Thailand version) does not give great proportion to Wibisana although he asks for political extradition to Rama, the protagonist character in the stories. But, Ramakien put greater proportion to Hanoman, who is considered as a character with super natural power. Even, romance scenes in Ramakien involve many variations [29].

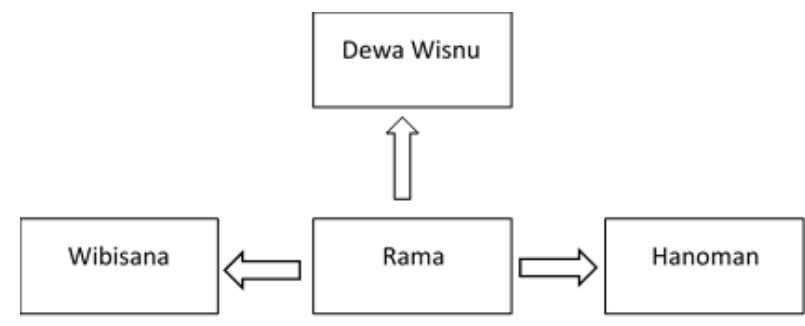

Scheme 1 Triangle of legitimacy for Rama power

The king is the only individual who holds power, who receives blessing by deity, and has authority to punish any person who intentionally disgrace royal dignity. In a very complex arrangement, Brahmana is the true representative of royal power and the keeper of royal dignity. Brahmana follows up this representation by establishing for the kings the worship sites designed to reflect Hindu culture order. In Java Island, the worship sites are mostly in the form of candi, and the stories that underlay the development of Hindu religion, including Ramayana stories, are carved on candi's wall. Therefore, in essence, it can be said that the position of Ramayana stories is always functional.

\subsection{Social Education}

Performing arts are used by the authorities of Indonesia and Thailand to play Ramayana stories. The transformation of Ramayana stories has made the stories no longer be used as "guidance" in educating people. Previously, this "guidance" is positioned as the base to condition people as the exemplary. Prince as potential king, therefore, must, since their childhood, learn a lot about exemplary behavior. Among various learnings about leadership is a leadership model taught by Rama to Barata and Wibisana. The ancient Javanese people have been familiar with leadership model and they call it "Hastabrata" [30]. This leadership model requires leaders to respect the nature (environment). However, the role of performing arts as social education begins to shift into entertainment realm. Education values become more implicit, while "visualization" aspect is given greater proportion on the spotlight to fulfill recreative function. This transformation shall make audiences become satisfied and bring pleasant memory along with them when they go home.

\section{CONCLUSION}

Aesthetical transformation on Ramayana stories of Indonesia and Thailand versions have been specifically mapped. The mapping sees the transformation through the lens of performing arts and also functional norms. The elements of aesthetical transformation on Ramayana stories are strongly related with the development of moral 
spiritual personality and the establishment of social mentality. Result of this research shows that local potentials of Indonesia and Thailand are greatly varying due to the dynamic sociocultural life of the people in both countries. Besides developing moral spiritual characteristic, Ramayana stories help spiritual advisor to establish people's social mentality in order to give more confirmation to the position of king. Ramayana stories are also used by spiritual advisor as an instrument of social education. However, over times, the concept of "guidance" (counseling people) in the play of Ramayana stories has been transformed into the concept of "visualization" where the stories become the recreative object of people (giving entertainment).

\section{AUTHORS' CONTRIBUTIONS}

The title "Aesthetical Transformation on Ramayana Stories of Indonesia- Thailand Versions" Authors' Contributions. Robby Hidajat, Pujiyanto, Hartono, Muh. Afaf Hasyimy

\section{ACKNOWLEDGMENTS}

Researchers would express a great gratitude to the LP2M of State University of Malang for giving trust to researchers to conduct investigation regarding the topic of research. Deep appreciation is given by researchers to all members of research team and also many informants for their input and support to this research. Sincere respect is extended to all institutions that have facilitated researchers to access relevant documents and to conduct observation on them, and to the individuals who allow researchers to make copy of those documents.

\section{REFERENCES}

[1] S. Soedjono, "Creative by Way of Adaption: Ramayana Relief of Prambanan Temple," J. Urban Soc. Arts, vol. 2, no. 2, pp. 104-110, 2015, doi: $10.24821 /$ jousa.v2i2.1447.

[2] S. Beggiora and V. Ca, "R ā $m$ ā ya ṇ a , il divino poema rivelato attraverso le maschere dei $\mathrm{R} \overline{\mathrm{a}} \mathrm{jban}$ śī 1," doi: 10.23814/ethn.13.17.beg.

[3] J. Choe and M. O'Regan, "Faith manifest: Spiritual and mindfulness tourism in Chiang Mai, Thailand," Religions, vol. 11, no. 4, 2020, doi: 10.3390/rel11040177.

[4] U. Peningkatan and K. Masyarakat, "ARKEOLOGI UNTUK MASYARAKAT : Peran Serta Kompleks Candi Prambanan dalam," Disk. Ilm. Arkeol. IAAI Komda Jabodetabek, no. September 2014, pp. 1-9.

[5] I Wayan Agus Gunada, "Ajaran Agama Hindu Sebagai Inspirasi Penciptaan Karya Seni Lukis Tradisional Bali," Gorga J. Seni Rupa, vol. 09, no.
1, pp. 158-165, 2020, doi: https://doi.org/10.24114/gr.v9i1.18492.

[6] A. A. Munandar, "International Review of Humanities Studies ARCHAEOLOGICAL ARTIFACTS AS EXPRESSIVE DESIRE OF HINDU-BUDDHA RELIGIONS IN JAVA International Review of Humanities Studies," vol. 4, no. 2, pp. 676-688, 2019.

[7] P. P. Wigaringtyas, "Kreativitas Nuryanto dalam Penciptaan Dramatari Ramayana," Gelar J. Seni Budaya, vol. 12, no. 1, pp. 44-57, 2014.

[8] I. M. Suweta, "Kepemimpinan Hindu: Dalam Nitisastra dan Susastra Hindu Ramayana Oleh:," Pariksa, vol. 3, no. 1, 2019.

[9] dkk. Robby Hidajat, Migrasi lakon Ramayana melalui seni pertunjukan wisata Indonesia-Thailand Abstrak, 1st ed. Malang: Penerbit Universitas Negeri Malang, 2019.

[10] S. Komariah and D. Wildan, "Sosietas Jurnal Pendidikan Sosiologi Pertunjukan Wayang sebagai Rekonstruksi Nilai Tuntunan dan Tontonan dalam Pembelajaran Sosiologi,” no. 1, pp. 754-764, 2020.

[11] N. W. Murniti, "Wayang Kulit Parwa Sebagai Media Transformasi Nilai Agama Hindu Bagi Generasi Melenial(Studi Deskriptif Pertunjukkan Wayang Kulit Lakon Pandawa Aguru Di Gria Perean Kediri, Tabanan," Haridracarya J. Pendidik. Agama Hindu, vol. 1, no. 1, 2020, doi: 10.1017/CBO9781107415324.004.

[12] I. Isbandiyah and S. Supriyanto, "Pendidikan Karakter Berbasis Budaya Lokal Tapis Lampung Sebagai Upaya Memperkuat Identitas Bangsa," KagangaJurnal Pendidik. Sej. dan Ris. Sos., vol. 2, no. 1, pp. 29-43, 2019, doi: 10.31539/kaganga.v2i1.673.

[13] R. W. Hermawan, "pertunjukan wayang kulitlakon murwakalasajian suyantodalam rangka ruwatan gebyak dalang(Kajian Struktur Dramatik dan Fungsi)," Feb. 2017.

[14] M. C. B. Umanailo, "TALCOT PARSON AND ROBERT K MERTON," doi: 10.31219/OSF.IO/9PMT3.

[15] A. Saidi, "Hermeneutika, Sebuah Cara Untuk Memahami Teks," J. Sosioteknologi, vol. 7, no. 13, pp. 376-382-382, 2008.

[16] J. Ilmiah, I. Agama, D. A. N. Ilmu, S. Budaya, and I. N. Aryanatha, "Jurnal Ilmiah Ilmu Agama Dan Ilmu Sosial Budaya Ritual Agama Hindu Dalam Membudayakan Nilai-Nilai Kearifan Lokal," vol. 13, no. 2, pp. 1-12, 2018. 
[17] Ketut Subagiasta, "Filosofi orang suci hindu dan peran kepemimpinan hindu," Inst. Agama Hindu Negeri TP Palangka Raya, 2018.

[18] I. Dalam, “Agama dan Negara di Indonesia Dalam Perspektif Sejarah," vol. 03, 2019.

[19] M. Riyani, "Penggambaran Etika Jawa Dalam Relief Wiracarita Ramayana Di Candi," 2005.

[20] E. R. Tunggono, Pemaparan penggambaran Tokoh Dalam Cerita Ramayana Di Relief Candi Panataran Di Blitar, Jawa Timur Dengan Penggambaran Tokoh Dalam Cerita Ramayana Pada Wayang, Tarian, Patung Dan Lukisan Di Bali., vol., no. 9. 2010.

[21] S. C. Pawana, "Titah Raja Kasultanan Yogyakarta Dalam Perspektif Teori Beslissingenleer Ter Haar," Justitia Pax, vol. 36, no. 1, pp. 109-126, 2020, doi: 10.24002/jep.v36i1.2260.

[22] I. G. Ngurah Seramasara, "Perubahan Kreativitas Seni Sebuah Proses Simbolis Dalam Kategori Sejarah," MUDRA J. Seni Budaya, vol. 32, no. 2, pp. 178-185, 2017.

[23] D. Iskandar, A. B. Sardjono, and . W., "Konsep Ruang Sakral dan Profan Pasar Gawok," Arsir, vol. 3, no. 2, p. 34, 2020, doi: 10.32502/arsir.v3i2.1950.
[24] N. H. Kistanto, "sistem sosial-budaya di indonesia Nurdien H . Kistanto Fakultas Sastra Universitas Diponegoro," Fak. Sastra Univ. Diponegoro, p. 1, 2011.

[25] P. Y. Marselia, "Pengaruh Agama Buddha Di Phuket Thailand Melalui Wat Chalong," pp. 1-16, 2019, doi: 10.31219/osf.io/5k9mr.

[26] A. Suwirta, "Raja , Wakil Allah , dan Manusia Sempurna: Wacana Pemikiran Politik Islam di Indonesia," 1994.

[27] S. Endrawara, "Ajaran budi pekerti luhur dalam sastra mistik penghayat kepercayaan untuk membangun pendidikan karakter bangsa," FBS Univ. Negeri Yogyakarta, vol. 53, no. 9, pp. 16891699, 2013, doi: 10.1017/CBO9781107415324.004.

[28] R. Hidajat, "Wayang Topeng Malang Dalam Perubahan Kebudayaan," Imaji, 2019, doi: 10.21831/imaji.v10i2.6379.

[29] R. Hidajat, "Sungai sebagai Transmisi Ritual Urban Kesuburan melalui Pertunjukan Wayang Topeng," J. Urban Soc. Arts, 2015, doi: 10.24821/jousa.v2i1.1264.

[30] I. Sutardjo, 'Konsep Kepemimpinan 'Hasthabrata' Dalam Budaya Jawa," Jumantara, vol. 5, no. 2, pp. 85-103, 2014. 